Pedagogik Jurnal Pendidikan, Maret 2015, Volume 10 Nomor 1, (40-50)

\title{
PENGGUNAAN METODE ROLE PLAYING DALAM MATA KULIAH PENGEMBANGAN BAHASA DAERAH MAHASISWA PGSD UNIVERSITAS MUHAMMADIYAH PALANGKARAYA
}

\author{
Oleh : Ichyatul Afrom*
}

\begin{abstract}
Abstrak
Penelitian ini bertujuan untuk mengetahui penggunakan metode role playing dalam mata kuliah pengembangan Bahasa Daerah pada mahasiswa semester III PGSD Universitas Muhammadiyah Palangkaraya tahun 2014/2015.

Metode dalam penelitian ini menggunakan metode eksperimen. Populasi dalam penelitian ini adalah mahasiswa semester III PGSD Universitas Muhammadiyah Palangkaraya tahun 2014/2015 yang berjumlah 35 orang. Sampel penelitian ini terdiri dari 35 orang mahasiswa, dari dua kelas dibagi menjadi dua kelompok yaitu kelas eksperimen dengan kelas kontrol.

Pengambilan sampel ditentukan dengan teknik penelitian populasi, dengan teknik pengumpulan data pre test dan pos test. Sedangkan teknik analisa data menggunakan rumus uji-t.

Hasil penelitian menunjukkan bahwa : hasil belajar Mata Kuliah Pengembangan Bahasa Daerah yang diajar menggunakan metode role playing lebih baik dibandingkan dengan hasil belajar Mata Kuliah Pengembangan Bahasa Daerah yang diajar menggunakan metode konfensional, mahasiswa terlihat lebih bersemangat dalam proses perkuliahan, karena mereka terlibat langsung dalam proses perkuliahan. Hal ini dapat dibuktikan dari hasil perhitungan bahwa $\mathrm{t}_{\text {hitung }}=3,093$ dan $\mathrm{t}_{\text {tabel }}=1,697$ karena $t_{\text {hitung }}(3,093)>t_{\text {tabel }}(1,697)$, maka hipotesis nol $\left(\mathrm{H}_{0}\right)$ ditolak. Dengan demikian Ha "ada perbedaan yang signifikan hasil belajar Mata kuliah Pengembangan Bahasa Daerah ditinjau dari penggunaan metode role playing dengan metode diskusi.
\end{abstract}

\section{Kata Kunci : Metode RolePlaying}

\section{PENDAHULUAN}

Suatu kenyataan bahwa manusia mempergunakan bahasa sebagai sarana komunikasi vital dalam hidup ini. Bahasa adalah milik manusia. Bahasa adalah salah satu ciri pembeda utama kita umat manusia dengan mahluk hidup di dunia ini. Setiap anggota masyarakat terlihat dalam komunikasi linguistik; di satu pihak dia bertindak sebagai pembicara dan di pihak lain sebagai penyimak.

Menurut Dinas Pendidikan dan Kebudayaan Kalimantan Tengah, bahasa daerah (lokal) terdapat pada 11 Daerah Aliran Sungai (DAS) yang meliputi 9 bahasa dominan dan 13 bahasa minoritas Bahasa Dominan: Bahasa Melayu, Bahasa Banjar, Bahasa Ngaju,
Bahasa Manyan, Bahasa Ot Danum, Bahasa Katingan, Bahasa Bakumpai, Bahasa Tamuan, Bahasa Sampit

Bahasa Kelompok Minoritas: Bahasa Mentaya, Bahasa Pembuang, Bahasa Dusun, Kalahien, Bahasa Balai, Bahasa Bulik, Bahasa Mendawai, Bahasa Dusun Bayan, Bahasa Dusun Tawoyan, Bahasa Dusun Lawangan, Bahasa Dayak Barean, Bahasa Dayak Bara Injey, Bahasa Kadoreh, Bahasa Waringin, Bahasa Kuhin (bahasa daerah pedalaman Seruyan Hulu).

Berdasarkan hasil pengamatan terhadap mahasiswa yang memprogramkan matak kuliah pengembangan Bahasa Daerah ditemukan adanya permasalahan. Permasalahan yang dijumpai adalah rendahnya aktivitas perkuliahan, mahasiswa 
banyak yang bicara sendiri dan terkesan bosan dengan materi yang diberikan. Oleh karena itu perlu diupayakan untuk mengatasi masalah-masalah tersebut dengan cara memperbaiki proses perkuliahan, salah satunya dengan penggunaan metode role playing.

Berdasarkan penjelasan di atas maka penulis tertarik untuk mengambil judul tentang "Penggunaan Metode Role Playing dalam Mata Kuliah Pengembangan Bahasa Daerah Mahasiswa PGSD FKIP Universitas Muhammadiyah Palangka Raya". Objek penelitian ini adalah Mahasiswa semester III PGSD FKIP UM Palangkaraya yang berjumlah 35 orang.

Berdasarkan permasalahan yang penulis paparkan di atas dapat dirumuskan masalah sebagai berikut : Bagaimana penggunaan metode role playing dalam Mata Kuliah Pengembangan Bahasa Daerah Mahasiswa PGSD, FKIP, Universitas Muhammadiyah Palangkaraya semester III tahun 2014-2015?

Suatu penelitian haruslah memuat tujuan penelitian. Sebab, setiap penelitian memiliki tujuan yang hendak dicapai. Dengan adanya tujuan maka akan dapat mengendalikan berbagai permasalahan yang akan menyimpang. Hal ini dikarenakan setiap penelitian mempunyai kaitan dengan perumusan yang dibahas. Adapun tujuan dalam penelitian ini adalah untuk mengetahui penggunaan metode role playing dalam Mata Kuliah Pengembangan Bahasa Daerah Mahasiswa PGSD, FKIP, Universitas Muhammadiyah Palangkaraya semester III tahun 2014-2015. Sesuai dengan tujuan penelitian maka secara teoretis penelitian ini dapat dijadikan sebagai sumber referensi untuk penelitian lebih lanjut secara mendalam.

a. Aspek yang dinilai untuk Mengetahui Keberhasilan Belajar pada Mata Kuliah
Pengembangan Bahasa Daerah pada aspek berbicara

Aspek yang dinilai adalah pada aspek berbicara. Hallim (dalam Depdiknas, 2009:3) mengatakan bahwa keefektifan berbicara juga dapat dipengaruhi oleh beberapa faktor, yaitu lafal atau ucapan dan pola-pola intonasi serta tekanan, penguasaan tata bahasa, kosa kata, kelancaran dan kefasihan dan pemahaman. Sehingga yang yang penting diamati pada aspek berbicara yaitu meliputi : intonasi, tekanan, tata bahasa, kosa kata, kelancaran kefasihan, dan pemahaman.

b. Komponen Alat Penilaian dan Deskripsi Kefasihan

Dipergunakan alat penilaian yang terdiri dari komponen-komponen tekanan, tata bahasa, kosa kata, kefasihan, dan pemahaman. Adapun deskripsi kefasihan untuk masingmasing komponen adalah sebagai berikut:

1) Tekanan

- ucapan sering tak dapat dipahami

- $\quad$ sering terjadi kesalahan besar dan aksen kuat yang menyulitkan pemahaman

- $\quad$ pengaruh ucapan asing (daerah) dan kesalahan ucapan yang dapat menyebabkan kesalah pahaman

- ucapan sudah standar

2) Tata Bahasa

- penggunaan tata bahasa hampir tidak selalu tepat

- kadang-kadang terjadi kesalahan dalam pengunaan pola tertentu

- $\quad$ sedikit terjadi kesalahan, tetapi bukan pada penggunaan pola 
3) Kosa Kata

- pengguaan kosa kata tidak tepat dalam percakapan yang paling sederhana sekalipun

- penguasaan kosa kata sangat terbatas

- pemilihan kosa kata sering tidak tepat dan keterbatasan penguasaannya mengahambat kelancaran komunikasi

4) Kelancaran

- pembicaraan selalu terhenti dan terputus-putus sehingga wawancara macet.

- Pembicara sangat lambat dan tak ajeg

- Pembicaraan sering tampak ragu, kalimat tidak lengkap

5) Pemahaman

- memahami sedikit isi percakapan yang paling sederhana

- memahami dengan lambat percakapan sederhana

- memahami dengan baik percakapan sederhana dalam hal tertentu masih perlu penjelasan dan pengulangan. Nur (2000).

\section{a. Metode Pembelajaran}

Metode berasal dari bahasa Yunani “ Methodos " yang berarti cara atau jalan yang ditempuh. Sehubungan dengan upaya ilmiah, maka metode menyangkut masalah cara kerja untuk dapat memahami objek yang menjadi sasaran ilmu yang bersangkutan. Fungsi metode berarti sebagai alat untuk mencapai tujuan. Metode juga diartikan suatu cara yang dipergunakan untuk mencapai tujuan yang telah ditetapkan. Dalam kegiatan belajar mengajar, metode diperlukan oleh pendidik dan penggunaannya bervariasi sesuai dengan tujuan yang ingin dicapai setelah pengajaran berakhir. Kata " mengajar" sendiri berarti memberi pelajaran.

Menurut Fathurrohman dan Sutikno (2007),

metode pembelajaran adalah cara-cara menyajikan bahan-bahan pelajaran kepada mahasiswa untuk tercapainya tujuan yang telah ditetapkan. Dengan demikian, salah satu keterampilan pendidik yang memegang peranan penting dalam pengajaran adalah keterampilan memilih metode. Oleh karena itu, salah satu hal yang sangat mendasaar untuk dipahami pendidik adalah bagaimana memahami kedudukan metode sebagai salah satu komponen bagi keberhasilan kegiatan belajar mengajar yang sama pentingnya dengan komponen-komponen lain dalam keseluruhan komponen pendidikan.

Menurut Djamarah, dkk (Fathurrohman dan Sutikno:2007), metode memiliki kedudukan:

- Sebagai alat motivasi ekstrinsik dalam proses pembelajaran

- Menyiasati perbedaan individual anak didik

- Untuk mencapai tujuan pembelajaran

Sebuah metode pembelajaran dapat menjadi alat motivasi ekstrinsik bagi mahasiswa. Dengan metode yang digunakan akan membuat mahasiswa tertarik dan aktif dalam belajar. Ketika seorang pendidik ingin memberikan materi drama pendek pada mata kuliah Pengembangan Bahasa Daerah maka metode yang sesuai adalah metode bermain peran, dengan metode bermain peran tersebut mahasiswa menjadi aktif dan termotivasi memerankan tokoh 
yang sesuai dengan materi yang diajarkan. Selain itu metode pembelajaran juga dapat menyiasati perbedaan individual anak didik, karena setiap mahasiswa tentunya memilliki karakteristik yang berbeda. Dengan metode tersebut pendidik dapat mengetahui letak perbedaan individual mahasiswa. Selanjutnya metode pembelajaran juga memiliki kedudukan untuk mencapai tujuan pembelajaran.

\section{Macam-macam Metode Pembelajaran}

Menurut Putra (2004), macam-macam metode pembelajaran adalah sebagai berikut:

1) Metode Ulang Ucap

2) Metode Lihat Ucap

3) Metode Memberikan Deskripsi

4) Metode Menjawab Pertanyaan

5) Metode Bertannya

6) Metode Pertanyaan Menggali

7) Metode Melanjutkan

8) Metode Menceritakan Kembali

9) Metode Bermain Peran (Role Playing)

10) Metode Parafrase

11) Metode Reka Cerita Gambar

12) Metode Memberi Petunjuk

13) Metode Pelaporan

14) Metode Wawancara

15) Metode Diskusi

16) Metode Ceramah

\section{b. Pengertian Metode Role Playing}

Menurut Oemar Hamalik, (2005), "role playing adalah suatu jenis teknik simulasi yang umumnya digunakan untuk pendidikan sosial dan hubungan antarinsani. Teknik ini melibatkan individu manusia dan tingkah laku mereka atau interaksi antar individu tersebut dalam bentuk dramatisasi. Para mahasiswa berpartisipasi sebagai pemain dengan peran tertentu atau sebagai pengamat (observer) bergantung pada tujuan-tujuan dari penerapan teknik tersebut". Menurut Martinis Yamin (2008), "metode role playing adalah metode yang melibatkan interaksi antara dua mahasiswa atau lebih tentang suatu topik atau situasi. Mahasiswa melakukan peran masingmasing sesuai dengan tokoh yang ia lakoni, mereka berinteraksi sesama mereka". Sedangkan menurut Rachmad Widodo (2003), " Metode role playing adalah suatu cara penguasaan bahanbahan pelajaran melalui pengembangan imajinasi dan penghayatan mahasiswa. Pengembangan imajinasi dan penghayatan ini dilakukan mahasiswa dengan memerankannya sebagai tokoh ".

\section{c. Tujuan Metode Role Playing}

Sesuai dengan jenis belajar, menurut Oemar Hamalik (2005 : 199), tujuan metode role playing adalah sebagai berikut:

1) Belajar dengan berbuat.

2) Belajar melalui peniruan (imitasi).

3) Belajar melalui balikan.

4) Belajar melalui pengkajian, penilaian, dan pengulangan.

Belajar dengan berbuat. Mahasiswa melakukan peranan tertentu sesuai dengan kenyataan yang sesungguhnya. Tujuannya adalah untuk mengembangkan keterampilanketerampilan interaktif atau keterampilan-keterampilan reaktif. Belajar melalui peniruan (imitasi). Para mahasiswa pengamat drama menyamakan diri dengan pelaku (aktor) dan tingkah laku mereka.

Belajar melalui balikan. Para pengamat mengomentari (menanggapi) perilaku para pemain atau pemegang 
peran yang telah ditampilkan. Tujuannya adalah untuk mengembangkan prosedur-prosedur kognitif dan prinsif-prinsif yang mendasari perilaku keterampilan yang telah didramatisasikan.

Belajar melalui pengkajian, penilaian, dan pengulangan. Para peserta dapat memperbaiki keterampilan-keterampilan mereka dengan mengulanginya dalam penampilan berikutnya.

\section{d. Kelebihan dan Kelemahan Metode Role Playing}

Kelebihan dari metode role playing adalah :

1) Mahasiswa melatih dirinya untuk melatih, memahami, dan mengingat isi bahan yang akan diperankan. Sebagai pemain harus memahami, menghayati isi cerita secara keseluruhan, terutama untuk meteri yang harus diperankannya. Dengan demikian, daya ingatan mahasiswa harus tajam dan tahan lama.

2) Mahasiswa akan terlatih untuk berinisiatif dan kreatif. Pada waktu bermain drama atau bermain peran, para pemain dituntut untuk mengemukakan pendapatnya sesuai dengan waktu yang tersedia.

3) Bakat yang terdapat pada mahasiswa dapat dipupuk sehingga dimungkinkan akan muncul atau tumbuh bibit seni drama dari sekolah. Jika seni drama mereka dibina dengan baik kemungkinan besar mereka menjadi pemain yang baik kelak.

4) Kerjasama antar-pemain dapat ditumbuhkan dan dibina dengan sebaik-baiknya.
5) Mahasiswa memperoleh kebiasaan untuk menerima dan dibina dengan sebaik-baiknya.

6) Bahasa lisan mahasiswa dapat dibina menjadi bahasa yang baik agar mudah dipahami orang lain.

Melalui metode bermain peran ini mahasiswa menjadi terbiasa dengan binaan-binaan dari pendidik mengenai bagaimana berperan yang baik.

\section{e. Prinsip Dasar dan Ciri-ciri Metode Role Playing}

Prinsip dasar dan ciri-ciri metode pembelajaran role playing. Menurut Nur (2000), prinsip dasar dari metode pembelajaran role playing adalah :

1) Setiap anggota kelompok (mahasiswa) bertanggung jawab atas segala sesuatu yang dikerjakan dalam kelompoknya.

2) Setiap anggota kelompok (mahasiswa) harus mengetahui bahwa semua anggota adalah tim.

3) Kelompok mempunyai tujuan yang sama.

4) Setiap anggota kelompok (mahasiswa) harus membagi tugas dan tanggung jawab yang sama diantara anggota kelompoknya.

5) Setiap anggota kelompok (mahasiswa) akan dikenai evaluasi.

6) Setiap anggota kelompok (mahasiswa) berbagi kepemimpinan dan membutuhkan keterampilan untuk belajar bersama selama proses belajarnya.

7) Setiap anggota kelompok (mahasiswa) akan diminta mempertanggung jawabkan secara individual materi yang ditangani dalam kelompok bermain

Prinsip dasar dari metode pembelajaran role playing yaitu, setiap 
anggota kelompok (mahasiswa) bertanggung jawab atas segala sesuatu yang dikerjakan dalam kelompoknya. Jadi setiap individu harus merasa memiliki tanggung jawab dan tidak membebankan hanya kepada satu orang saja.

Setiap anggota kelompok (mahasiswa) harus mengetahui bahwa semua anggota adalah tim. Ini berati, tidak ada satu anggaotapun yang tidak tahu atau bahkan melupakan timnya. Kelompok mempunyai tujuan yang sama. Dalam bermain peran sebuah kelompok harus mempunyai tujuan yang sam agar tujuan yang dinginkan oleh kelompok dapai dicapai secara bersama-sama. Kemudian Setiap anggota kelompok (mahasiswa) harus membagi tugas dan tanggung jawab yang sama diantara anggota kelompoknya. Tanggung jawab dibebankan kepada masing-masing anggota dalam kelompok.

Sedangkan ciri-ciri metode pembelajaran role playing adalah sebagai berikut:

1) Mahasiswa dalam kelompok secara bermain menyelesaikan materi belajar sesuai kompetensi dasar yang akan dicapai.

2) Kelompok dibentuk dari mahasiswa yang memiliki kemampuan yang berbeda-beda, baik tingkat kemampuan tinggi, sedang dan rendah. jika mungkin anggota kelompok berasal dari ras, budaya, suku yang berbeda serta memperhatikan kesetaraan jender.

3) Penghargaan lebih menekankan pada kelompok dari pada masingmasing individu.

Mahasiswa dalam kelompok secara bermain menyelesaikan materi belajar sesuai kompetensi dasar yang akan dicapai. Jadi materi yang diajarkan bukan materi asal-asalan, melainkan materi tersebut harus sesuai dengan kompetensi dasar yang akan dicapai. Kemudian kelompok dibentuk dari mahasiswa yang memiliki kemampuan yang berbeda-beda, baik tingkat kemampuan tinggi, sedang dan rendah. jika mungkin anggota kelompok berasal dari ras, budaya, suku yang berbeda serta memperhatikan kesetaraan jender. Ini karena, dalam sebuah drama biasa diperlukan berbagai mcam karakter, sehingga dalam satu kelompok harus dibentuk dengan tingkat kemampuan yang berbeda.

Selanjutnya penghargaan lebih menekankan pada kelompok dari pada masing-masing individu. Karena yang lebih diperhatikan dalam sebuah drama adalah, kekompakan dan kerjasama dari suatu kelompok.

\section{f. Peranan Metode Role Playing dalam Proses Pembelajaran}

Menurut Alhafidzh (2010), peranan metode role playing dalam proses pembelajaran adalah sebagai berikut :

- Pelajaran dimaksudkan untuk melatih dan menanamkan pengertian dan perasaan seseorang.

- Pelajaran dimaksudkan untuk menumbuhkan rasa kesetiakawanan sosial dan rasa tanggung jawab dalam memikul amanah yang telah dipercayakan.

- Apabila dimaksudkan untuk mendapatkan keterampilan tertentu sehingga diharapkan mahasiswa mendapatkan bekal pengalaman yang berharga, setelah mereka terjun dalam masyarakat kelak.

- Dapat menghilangkan malu.. 
- Untuk mengembangkan bakat dan potensi yang dimiliki oleh mahasiswa sehingga amat berguna bagi kehidupannya dan masa depannya kelak.

Pelajaran dimaksudkan untuk melatih dan menanamkan pengertian dan perasaan seseorang. Melalui peran yang dibawakan, mahasiswa tentukan bukan menjadi diri sendiri melainkan menjadi tohoh yang mereka perankan. Dengan berperan sebagai orang lain, mahasiswa diharapkan dapat menanamkan pengertian dan perasaan orang lain. Pelajaran dimaksudkan juga untuk menumbuhkan rasa kesetiakawanan sosial dan rasa tanggung jawab dalam memikul amanah yang telah dipercayakan. Jadi, dalam bermain peran tersebut tanggung jawab tidak diberikan hanya pada satu orang melainkan dipikul bersama oleh kelompok drama, dengan adanya tanggung jawab bersama diharapkan akan tumbuh rasa kesetikawanan sosial.

\section{g. Langkah-langkah Pembelajaran dengan Metode Role Playing}

Menurut Rachmad Widodo (2003), langkah-langkah pembelajaran dengan metode role playing adalah :

1) Pendidik menyusun atau menyiapkan skenario yang akan ditampilkan

2) Menunjuk beberapa mahasiswa untuk mempelajari skenario dalam waktu beberapa hari sebelum pelaksanaan proses pembelajaran

3) Pendidik membentuk kelompok mahasiswa yang anggotanya lebih dari 2 orang

4) Memberikan penjelasan tentang kompetensi yang ingin dicapai
5) Memanggil para mahasiswa yang sudah ditunjuk untuk melakonkan skenario yang sudah dipersiapkan

6) Masing-masing mahasiswa berada dikelompoknya sambil mengamati scenario yang sedang diperagakan

7) Setelah selesai ditampilkan, masingmasing mahasiswa diberikan lembar kerja untuk membahas atau memberikan penilaian atas masingmasing kelompok

8) Masing-masing kelompok menyampaikan hasil kesimpulannya

9) Pendidik memberikan kesimpulan secara umum

10) Evaluasi

11) Penutup

Metode merupakan hal yang sangat penting dalam penelitian. Sebab tanpa ada metode, penelitian ini tidak dapat dipertanggung jawabkan secara ilmiah. Berdasarkan uraian tersebut penelitian ini menggunakan metode eksperimen. Pengertian eksperimen adalah mengadakan percobaan untuk melihat suatu hasil.

Menurut Nana Sudjana dan Ibrahim (Samsudinor, 2010:23), menyatakan bahwa:

Metode ini mengungkapkan hubungan antara dua variabel atau lebih atau mencari pengaruh suatu variabel terhadap variabel lain. Penelitian eksperimen mengandung tiga ciri pokok yakni :

1. Adanya variabel bebas yang dimanipulasikan

2. Adanya pengendalian/ pengontrolan secara variabel kecuali variabel bebas

3. Adanya pengamatan/ pengukuran terhadap variabel terikat sebagai variabel efek variabel bebas. 
Pedagogik Jurnal Pendidikan, Maret 2015, Volume 10 Nomor 1, (40-50)

\section{PEMBAHASAN}

Berdasarkan hasil penelitian yang telah dilakukan diperoleh hasil yang menggunakan metode role playing dalam mata kuliah Pengembangan Bahasa Daerah adalah pada $t$ hitung 3,093 dan $t$ tabel 1,697 pada taraf signifikansi $5 \%$, berarti bahwa $\mathrm{t}$ hitung $>\mathrm{t}$ tabel atau 3,093 > 1,697. Hal ini berarti terdapat perbedaan hasil belajar mata kuliah antara pembelajaran yang menggunakan metode role playing dengan pembelajaran yang menggunakan metode konfensional. Hal ini membuktikan bahwa proses perkuliahan Pengembangan Bahasa Daerah yang menggunakan metode role playing hasilnya lebih maksimal.

1. Kemampuan Prasyarat (kemampuan awal sebelum perlakuan)
Kemampuan prasyarat ini diberikan kepada kelas IVA (eksperimen) dan IVB (eksperimen) untuk melihat kemampuan awal yang dimiliki oleh kedua kelas tersebut. Teknik untuk pengumpulan datanya berupa tes, dan jenis tesnya lisan. Jumlah penilaian mengacu pada 6 pedoman tes yang telah di validasi melalui validator. Setelah diberikan pretest, Kemudian kedua kelas tersebut dilihat perbedaannya yang berupa kemampuan prasyarat

Berdasarkan hasil tes kemampuan awal yang diperoleh peserta didik. Hal ini dapat di lihat pada tabel data skor kemampuan awal, yaitu sebagai Berikut

Skor Nilai Pre-tes Kelas Eksperimen A

\begin{tabular}{|c|c|}
\hline Kode peserta didik & Nilai hasil pre-tes kelas IVA \\
\hline 001 & 13 \\
\hline 002 & 9 \\
\hline 003 & 11 \\
\hline 004 & 10 \\
\hline 005 & 6 \\
\hline 006 & 11 \\
\hline 007 & 8 \\
\hline 008 & 6 \\
\hline 009 & 7 \\
\hline 010 & 8 \\
\hline 011 & 11 \\
\hline 012 & 7 \\
\hline 013 & 11 \\
\hline 014 & 7 \\
\hline 015 & 12 \\
\hline 016 & 8 \\
\hline 017 & 10 \\
\hline 018 & 12 \\
\hline Jumlah skor & 167 \\
\hline$\overline{X_{1}}$ & 9,3 \\
\hline
\end{tabular}


Pedagogik Jurnal Pendidikan, Maret 2015, Volume 10 Nomor 1, (40-50)

Mencari perhitungan nilai rata-rata $(\bar{X})$ dan variansi $\left(S^{2}\right)$ pada :

1) Kelas Eksperimen

Kemampuan Awal (Pre Test)

Perhitungan untuk Memperoleh Nilai Rata-Rata $\left(\bar{X}_{1}\right)$ Dan Variansi $\left(S_{1}^{2}\right)$

\begin{tabular}{|c|c|c|c|c|c|}
\hline Data $X_{1}$ & (F) & F.X & $\begin{array}{c}\mathrm{F} \\
\text { Komulatif }\end{array}$ & $\mathrm{X}_{1}^{2}$ & F.X. ${ }_{1}^{2}$ \\
\hline 13 & 1 & 13 & 1 & 169 & 169 \\
\hline 12 & 2 & 24 & 3 & 144 & 288 \\
\hline 11 & 4 & 44 & 7 & 121 & 484 \\
\hline 10 & 2 & 20 & 9 & 100 & 200 \\
\hline 9 & 1 & 9 & 10 & 81 & 81 \\
\hline 8 & 3 & 24 & 13 & 64 & 192 \\
\hline 7 & 3 & 21 & 16 & 49 & 147 \\
\hline 6 & 2 & 12 & 18 & 36 & 72 \\
\hline Jumlah & $\sum F=18$ & 167 & & & $\sum F \cdot X_{1}^{2}=1633$ \\
\hline
\end{tabular}

a. Nilai Rata-Rata $\left(\bar{X}_{1}\right)$

$\mathrm{X}_{1}=\frac{\sum F X_{1}}{\sum F}=\frac{157}{18}=\mathbf{9}, \mathbf{3}$

b. Variansi $\left(S_{1}^{2}\right)$

$$
\begin{aligned}
& \mathrm{S}_{1}^{2}=\frac{\sum F X_{1}^{2}}{N}-\left[\frac{\sum F X_{1}}{N}\right]^{2} \\
& \mathrm{~S}_{1}^{2}=\frac{1633}{18}-\left[\frac{167}{18}\right]^{2} \\
& \mathrm{~S}_{1}^{2}=90,72-[9,27]^{2} \\
& \mathrm{~S}_{1}^{2}=90,72-85,93 \\
& \mathrm{~S}_{1}^{2}=\mathbf{4 , 7 9}
\end{aligned}
$$


Pedagogik Jurnal Pendidikan, Maret 2015, Volume 10 Nomor 1, ( 40 - 50 )

Skor Nilai Post-tes Kelas Eksperimen IVA yang menggunakan metode role playing

\begin{tabular}{|c|c|}
\hline Kode peserta didik & Nilai hasil post-tes kelas IVA \\
\hline 001 & 14 \\
\hline 002 & 12 \\
\hline 003 & 17 \\
\hline 004 & 12 \\
\hline 005 & 16 \\
\hline 006 & 17 \\
\hline 007 & 11 \\
\hline 008 & 9 \\
\hline 009 & 16 \\
\hline 010 & 12 \\
\hline 011 & 13 \\
\hline 012 & 14 \\
\hline 013 & 16 \\
\hline 014 & 10 \\
\hline 015 & 15 \\
\hline 016 & 9 \\
\hline 017 & 16 \\
\hline 018 & 16 \\
\hline Jumlah skor & 246 \\
\hline$\overline{\boldsymbol{X}}_{1}$ & 13,66 \\
\hline
\end{tabular}

Mencari perhitungan nilai rata-rata $(\bar{X})$ dan variansi $\left(\mathrm{S}^{2}\right)$ pada :

Kemampuan Akhir (Post Test)

1) Kelas Eksperimen

Perhitungan untuk Memperoleh Nilai Rata-Rata $\left(\bar{X}_{1}\right)$ dan Variansi $\left(S_{1}^{2}\right)$

\begin{tabular}{|c|c|c|c|c|c|}
\hline Data $X_{1}$ & (F) & F.X & $\begin{array}{c}\mathbf{F} \\
\text { Kumulatif }\end{array}$ & $\mathbf{X}_{1}{ }^{2}$ & F. $X_{1}{ }^{2}$ \\
\hline 17 & 2 & 34 & 2 & 289 & 578 \\
\hline 16 & 5 & 80 & 7 & 256 & 1280 \\
\hline 15 & 2 & 30 & 9 & 225 & 450 \\
\hline 14 & 1 & 14 & 10 & 196 & 196 \\
\hline 13 & 1 & 13 & 11 & 169 & 169 \\
\hline 12 & 3 & 36 & 14 & 144 & 432 \\
\hline 11 & 1 & 11 & 15 & 121 & 121 \\
\hline 10 & 1 & 10 & 16 & 100 & 100 \\
\hline 9 & 2 & 18 & 18 & 81 & 162 \\
\hline Jumlah & $\sum F=18$ & 246 & & & $\sum F \cdot X_{1}^{2}=3488$ \\
\hline
\end{tabular}


Pedagogik Jurnal Pendidikan, Maret 2015, Volume 10 Nomor 1, (40-50)

a. Nilai Rata-Rata $\left(\bar{X}_{1}\right)$

$\mathrm{X}_{1}=\frac{\sum F X_{\mathrm{S}}}{\sum F}=\frac{246}{18}=13,66$

b. Variansi $\left(S_{1}^{2}\right)$

$$
\begin{aligned}
& \mathrm{S}_{1}^{2}=\frac{\sum F x_{1}^{2}}{N}-\left[\frac{\sum F x_{1}}{N}\right]^{2} \\
& \mathrm{~S}_{1}^{2}=\frac{3488}{18}-\left[\frac{246}{18}\right]^{2} \\
& \mathrm{~S}_{1}^{2}=193,77-[13,66]^{2} \\
& \mathrm{~S}_{1}^{2}=193,77-186,59 \\
& \mathrm{~S}_{1}^{2}=\mathbf{7 , 1 8}
\end{aligned}
$$

Berdasarkan penjelasan di atas berarti metode role playing dapat dijadikan sebagai metode alternatif dalam perkuliahan Pengembangan Bahasa Daerah. Selain itu, dengan menerapkan metode role playing pada mata kuliah Pengembangan Bahasa Daerah, mahasiswa lebih tertarik dan aktif .

\section{SIMPULAN}

Berdasarkan penjelasan di atas berarti metode role playing dapat dijadikan sebagai metode alternatif dalam perkuliahan Pengembangan Bahasa Daerah. Selain itu, dengan menerapkan metode role playing pada mata kuliah Pengembangan Bahasa Daerah, mahasiswa lebih tertarik dan aktif

\section{DAFTAR PUSTAKA}

Alhafidzh, (2010), http://ziazone.wordpress.com/2011/07/01/pembelajaran-metode-roleplaying pada-pasar-persaingan-sempurna/ 02 Pebruari 2012

Halim, (Depdiknas 2009). Pembelajaran Berbicara. Jakarta: PT. Remaja Rosdakarya

Ihat Hatimah, dkk (2007), Pembelajaran Berwawasan Kemasyarakatan, Jakarta : Universitas Terbuka

Moh. Nazir, (2005), Metodologi Penelitian, Bogor : Ghlia Indonesia

Oemar Hamalik, (2005), Perencanaan Pengajaran Berdasarkan Pendekatan Sistem, Bandung : PT. Bumi Aksara

Sardiman, A. M., (2001), Interaksi dan motivasi Belajar Mengajar, Jakarta : PT. Raja Grafindo. 